\title{
Upbringing Towards the "Highest" Values in the Activities and Program of "Eleusis" During the Period of National Captivity
}

\begin{abstract}
The turn of the 19th and 20th centuries brought an unprecedented number of youth organizations and movements in Galicia, which can be divided into three basic groups: the sports-tourism-gymnastic movement, the military movement and the ethical-revival movement. One of them was "Eleusis" movement initiated by Wincenty Lutosławski (1863-1954), a well-known philosopher, member of the Academy of Skills, and also the brother of Kazimierz Lutosławski, the legendary creator of the Scout Cross. "Eleusis" existed in the years 1903-1920, its aim was to prepare young Poles for the struggle for independence by educating their morals. "Eleusis" rejected violence and armed struggle. "Eleusis" was a strictly Catholic organization - a kind of secular order. However, it never received the official blessing of the Catholic Church.

Many Eleusis members later joined the ranks of the Polish scouts and it is thanks to the Eleusian spirit that Polish scouting has the rule of alcohol and tobacco abstinence in its Scouting Law. Whereas, the meaning and influence of scouts on Polish youth is undisputed today.
\end{abstract}

Keywords: Eleusis Movement, Wincenty Lutosławski, polish scouting history

The turn of the 19th and 20th centuries brought an unprecedented number of youth organizations and movements in Galicia, which can be divided into three basic groups: the sports-tourism-gymnastic movement, the military movement and the ethical-revival movement ${ }^{1}$. The form of their activities and their content often referred to youth organizations from the first half of the 19th century ${ }^{2}$ (e.g.: The Polish Gimnastic Association

\footnotetext{
${ }^{1}$ GRABSKI, S., Harcerstwo wśród organizacyj młodzieży, [in:] Harcerstwo polskie, ed. S. SEDLACZEK and L. GRABOWSKI, Warsaw 1925.

2 KAMIŃSKI, A., Polskie związki młodzieży (1804-1931), Warsaw 1963.
} 
"Sokół"3, the Union of Polish Youth "Zet"4 and the Organization of Independent Youth "Zarzewie"5).

At the turn of the centuries, national ideology became particularly popular among the youth. It was supported by Stanisław Prus-Szczepanowski (1846-1900), Zygmunt Balicki (1858-1916) and Lucjan Zarzecki (1873-1925). The former deserves particular attention due to the fact that in his ideology he was able to combine romantic elements (in terms of goals) with positivist ones (when talking about means), which no one before him had done $^{6}$. He was convinced that Poland was able to create a concept of a new type of humanmodel, being an expression of the needs of modern society ${ }^{7}$, a citizen type, being a synthesis of the heroic elements of the Polish soul, bred during the long period of knightly culture, spiritualized by romantic poets and philosophers, with the characteristics of the worker, so desired by the positivists ${ }^{8}$. Like Polish romantics, Prus-Szczepanowski believed in the extraordinary mission of the Polish nation, which was strongly connected with religion and mysticism. He was a supporter of the spiritual revival of Poles and today his system is rightly known as one of the highest effort and heroism ${ }^{9}$.

The movement that linked the views of S. Prus-Szczepanowski with the ethical-revival-abstinence trend was the most controversial, intriguing and at the same time mysterious organization of those times - "Eleusis"10. This movement was initiated by Wincenty Lutosławski (1863-1954)11, a well-known philosopher, lecturer in Moscow, Kazan, Krakow, Geneva, Lausanne, London, Dorpat and Vilnius, member of the Academy of

${ }^{3}$ MIRKIEWICZ, M., Towarzystwo Gimnastyczne "Sokót”. Mit a rzeczywistość, [in:] Galicja i jej dziedzictwo, ed. A. MEISSNER and J. WYROZUMSKI, vol. 3, Rzeszów 1995, p. 269-281; Leksykon harcerstwa, ed. O. FIETKIEWICZ, Warsaw 1988, p. 433-434; TOPOROWICZ, K., “Geneza i rozwój organizacyjny Towarzystwa Gimnastycznego Sokót w Krakowie w latach 1885-1914”, Rocznik Naukowy Wyższej Szkoły Wychowania Fizycznego w Krakowie, vol. 5, 1966, p. 63-113. See: HAUSNER, W., Krakowski skauting 1910-1914, Kraków 1994; BŁAŻEJEWSKI, W., Z dziejów harcerstwa polskiego 1910-1939, Warsaw 1985, p. 20-26.

4 "Zet" w walce o niepodległość i budowę państwa. Szkice $i$ wspomnienia, ed. T.W. NOWACKI, Warsaw 1996; Leksykon harcerstwa, op. cit., p. 528-529; BŁAŻEJEWSKI, W., 50 lat harcerstwa w Polsce, Dział Rękopisów Zakładu Narodowego im. Ossolińskich, manuscript, ref. no. 14998.

5 BAGIŃSKI, H., "Geneza polskiego skautingu”, Harcerstwo, 1934, no. 2, p. 55-65; Idem, Geneza polskiego skautingu, Warsaw 1937; Idem, U podstaw organizacji wojska polskiego 1908-1914, Warsaw 1935; Leksykon harcerstwa, op. cit., p. 520.

${ }^{6}$ KUBERSKI, L., Stanisław Szczepanowski 1846-1900. Przemysłowiec. Polityk. Publicysta, Opole 1997.

7 NAWROCZYŃSKI, B., Polska myśl pedagogiczna, Warsaw-Lwów 1938, p. 132.

${ }^{8}$ Ibidem, p. 133. Por. ARASZKIEWICZ, F.W., Idealy wychowawcze Drugiej Rzeczypospolitej, Warsaw 1978 , p. 32-37.

${ }^{9}$ Ibidem.

${ }^{10}$ Materials for the history of scouts - Eleusis, ZHP Archive, Archive of New Records, ref. no. 76/539; STRUMiŁŁO, T., "Nasze dzieje", Harcmistrz, 1925, no. 2, p. 13.

${ }^{11}$ LEONHARD, B., Harcerski stowniczek abstynencki, Kraków 1992, p. 106; Encyklopedia Historii Drugiej Rzeczypospolitej, Warsaw 1999, p. 206. 
Skills, and also the brother of Kazimierz Lutosławski, the legendary creator of the Scout Cross $^{12}$.

"Eleusis" existed in the years 1903-1920 and in its initial phase it was a loose group of people professing his [i.e. Lutosławski's - E.G.-S.] ideology and indivisible leadership ${ }^{13}$. Its members were recruited from the activists of the abstinence Society "Eleuteria" 14 and the "Sobriety" Society, which promoted abstinence from "alcoholic" beverages and supported all attempts aimed at distracting people from such beverages ${ }^{15}$. In their activities, the said societies also included founding sanatoriums, hospitals and outpatient clinics for alcoholics and their treatment. They also positively evaluated any laws directed against drinking. "Eleuteria" was also a work of W. Lutosławski ${ }^{16}$.

"Eleusis", a somewhat mysteriously sounding word, is the name of a city in ancient Greece, where people free of addictions and low passions held their mysteries (the Hellenic Capital, where the chosen ones were initiated and confirmed in the possession of those eternal truths on which the progress of the spirit depends on the earth $)^{17}$ Members of "Eleusis" called themselves "Elses" (when referring to each other, they used the phrases: sister and brother ${ }^{18}$ ), and the name came from the first letters of the Greek sentence: Eleutheroi laon sotheres, which means: "The free shall be the saviours of people"19. Many Elses, brought up in the cult of Romanticism, understood it too literally.

Members of "Eleusis" vowed for a lifetime, quadruple self-restraint: from alcohol, tobacco, cards and debauchery ${ }^{20}$. In order to abide by such abstinence, they were

12 KARWOWSKI, H.F., Ks. Prałat dr Kazimierz Lutosławski, twórca krzyża harcerskiego, Łomża 1997.

13 JACHOWSKI, J., Harcmistrz Rzeczypospolitej (Tadeusz Strumiłto 1884-1958), [in:] Byli wśród nas, ed. F. LENORT, Poznań 1978, p. 205-218.

14 ZAGÓRSKI, Z., "Eleuteria - Wyzwolenie (1902-1914)", Problemy Alkoholizmu, 1973, no. 3, p. 24-25.

15 Statutes of the "Eleuteria" Society and the "Sobriety" Society, the Galician Governors in Lviv, the Central State Historical Archives of Ukraine. Branch in Lviv, ref. no. 146/58/3061-62, 3065-66.

${ }^{16}$ It was founded in 1902. Apart from Lviv, it also expanded its operations in Kraków, Biecz, Przemyśl, Czerniowce, Stanisławów, Tarnopol, Kosów and Jarosław. Members of Eleuteria organized Polish anti-alcoholic congresses in 1904, 1905 and 1912, educational and publishing campaigns, the closing of pubs on Sundays and holidays, supported in the local government elections only those deputies and councilors who manifested their abstinence. Eleuteria gathered many outstanding figures in its ranks: Dybowski, Bujwid, Zapolska, Konopnicka, Sienkiewicz, Małkowski, Strumiłło, Daszyńska-Golińska. See: LEONHARD, B., op.cit.

${ }^{17}$ Leksykon harcerstwa, op. cit., p. 87; LEONHARD, B., op.cit., p. 51-52.

${ }^{18}$ Due to clandestine reasons, however, pseudonyms were used, often referring to names related to nature.

19 Lutosławski's opponents gave a slightly different, in their understanding blasphemous, etymology of the word. Els was also an abbreviation of three Hebrew words: Eli lamma sabachtani, spoken by Christ on the cross. This would mean that the society was created in response to this call ...

${ }^{20}$ Statute of the Academic Society "Eleusis", Galician Governorship ..., ref. no. 146/58/3065; LEONHARD, B., "U źródeł profilaktyki przeciwalkoholowej w harcerstwie", Problemy Alkoholizmu, 1970, no. 10, p. $22-24$. 
obliged by: the word of honour, church vows and solemn vows. The vows resulted from need to prepare young Poles for the struggle for independence by educating their morals. "Eleusis" rejected violence and armed struggle. In addition, the motivation of the young people to stay abstinent was based on two pillars: the fight against the tendency of the invaders to encourage the Polish society to drink and the struggle for the biological fullness of Poles, their family happiness and professional prosperity. The motive of self-development was also important, which could positively affect the surroundings of a young man who could openly manifest his abstinence ${ }^{21}$. He was assisted with Indian yogic exercises, Catholic practices, the writings of Polish messianism, and educational work among people. Members were subject to strict regulations, especially when it came to regular contributions and attendance at meetings (e.g. Lviv members gathered every Sunday, in the early morning, sometimes even at $4 \mathrm{am}$, in the house of Mrs. Krasuska, near the church of St. Jura).

The Society was funded by contributions from its members, from public lectures, from publishers and from the donations of benefactors. The "Eleusis" Statute guaranteed help, in the form of special boarding houses, lectures, libraries, for young people who studied privately ${ }^{22}$. There was a hierarchy among the members. They were divided into: trial, ordinary, free and honorary members. Every ordinary and extraordinary student of University (the Jagiellonian University in the case of Krakow). who belonged to the Catholic Church, could become a trial member. He could change his status after the trial year, or earlier if the authorities agreed. Free members, on the other hand, were chosen unanimously from among ordinary members for their special merits. Honorary members were, in the light of the Statutes, to be indicated at the request of the Society's authorities from among the professors. The authorities of "Eleusis" included: the Department, consisting of the secretary, treasurer, their deputies and the host, the Meeting of all free members, the Meeting of ordinary and trial members and the Society's Curator. The latter was elected by the Faculty of Theology 23 .

"Eleusis" was a strictly Catholic organization - a kind of secular order. However, it never received the official blessing of the Catholic Church. On the contrary, Lutosławski and his "children" were often accused of heresy and hypocrisy ${ }^{24}$. The removal of "Lutos" (as Lutosławski was unofficially known among the members) from the post of assistant professor at the Jagiellonian University was used for this purpose ${ }^{25}$. Church environ-

${ }^{21}$ KAMIŃSKI, A., Andrzej Małkowski, Warsaw 1979, p. 13.

22 Statute of the Academic Society “Eleusis”..., op. cit.

${ }^{23}$ A detailed description of the formation of the organizational structure and development of the territorial network of circles is contained in the work of PODGÓRSKA, T., Stowarzyszenie Patriotyczno-Religijne Eleusis w latach 1902-1914, Lublin 1999, p. 53-102.

${ }^{24}$ See e.g.: MAJEWSKI, F.K., Czy Eleusis pana Lutosławskiego jest katolickim czy masońskim zakonem?, Częstochowa 1910.

25 The Academic Senate even sent a letter to the Governship, in which it criticized the statutes of the Academic Society "Eleusis" (briefly discussed in the text), which it was to approve. The Senate asked in this letter not to accept the statute, as it remained under the direction of Dr. Lutosławski, who is unhealthy, mischievous 
ments were also afraid of the chaos and confusion, which the slogans of the members and their "Father-Initiator" could cause in the way thinking of the Polish society ${ }^{26}$. It was also disturbing that Lutosławski repeatedly referred to ancient traditions and customs, which was perceived by his opponents as a mere manifestation of paganism and masonic patterns. The people of the Church were not convinced even by the vows of abstinence ... Especially that Lutosławski's understanding of sexual abstinence was not compatible with the official position of the Church. The church also condemned the principle of co-education, promoted in "Eleusis".

"Eleusis" edited its own, jointly prepared, publications. The most important were the subsequent volumes of "Eleusis". Six were published, the seventh, written already in reborn Poland, containing the recollections of deceased members, partly written by Tadeusz Strumiłło, was not published due to the outbreak of World War II. A similar fate was shared by the "Eleusinian Breviary", elaborated by the members on the basis of the Holy Scriptures, the writings of the Fathers of the Church, the lives of the saints, the works of the bards, Norwid, Towiański. This text was also lost due to warfare ${ }^{27}$.

The Eleusians attributed a significant role to national bards, national philosophy (which was to break all connections with the positivist plague), by Lutosławski himself ${ }^{28}$, where the key concept was that of the nation ${ }^{29}$. His system understood national consciousness not as a uniformity of race, but of spirit, because it was the only concept that could result in common national aspirations. And national consciousness is born as a result of shared experiences of the whole group, it is also deepened by artistic and literary creativity. According to Lutosławski, a model example of the nation was the Polish nation, created on the basis of the experience and history of many tribes, ethnic groups and peoples. "Master Wincenty", however, was an opponent of racial pride and believed in the union of nations (initiated by Poland in the 14th century), especially the smaller ones. Smaller states are unable to secure their independence in a different way, only through joining and creating a greater power.

National ideology in the Eleusian version was very similar to Polish messianism, and its popularity at the beginning of the $20^{\text {th }}$ century was the result of the revival of romantic slogans in the form of neoromantic ideology. The Eleusian movement was a phenomenon characteristic of the turn of the century, it testified to a change in the mood among Polish youth, which was no longer satisfied with the lifestyle proposed by the spirit of Young Poland. Lutosławski himself was known for his hostile attitude towards "przybyszewszczyzna".

and harmful to young people, the Galician Governorship in Lviv, Central State Historical Archives of Ukraine. Branch in Lviv, ref. no. 146/58/3065.

${ }_{26}$ Thus, Lutosławski was compared to the greatest "troublemakers" of the $19^{\text {th }}$ century, including Andrzej Towiański.

27 JACHOWSKI, J., op.cit., p. 208.

${ }_{28}$ In 1902 Lutosławski also founded the National Education Seminar.

29 LUTOSŁAWSKI, W., "Filozofja narodowa", Przegląd Filozoficzny, 1934, 37; LEONHARD, B., Harcerski stowniczek..., op. cit., p. 106. 
B. Nawroczyński characterized Lutosławski's system as pluralistic spiritualism, combined with faith in the pre-existence of individual souls and metempsychosis. In addition to immortal individual selves, there are national selves ${ }^{30}$.The perfection of the self as such consists in gaining a greater awareness of its spiritual identity and vocation. According to Lutosławski, the Polish nation has a special role to fulfil - to save others. When Poles fulfil their task properly, the rest of the nations will organize all humanity on the principles of love, resulting in the implementation of the Kingdom of God on earth.

Władysław Tatarkiewicz included Lutosławski, along with Stanisław Brzozowski and Edward Abramowski, to the philosophical trend called spiritualism. He noted, however, the distinction of the metaphysics of the former, as it proclaimed not only the uniqueness of the spirits, but also a multiplicity of their incarnations, palingenesis. It merged with the mystical theory of cognition. And put a special emphasis on the idea that the highest metaphysical reality is the nation, and the highest source of cognition is national conscious$n e s s^{31}$. Lutosławski considered himself a student of Plato, but he interpreted the idealistic philosophy, as everything else, in his own spiritual way.

The philosophy of W. Lutosławski never gained wider recognition in Poland; during the period of its greatest popularity in 1907, "Eleusis" had several hundred members in all partitions. The groups most influenced by "Eleusis" were students and workers (the educational campaign was conducted among them in Upper Silesia, Rhineland and Westphalia ${ }^{32}$ ). It is hard not to notice, however, that Lutosławski was an extraordinary figure. Olga Małkowska, the founder of girls scouting shared a very warm memory of him. She described him as an excellent philosopher, a wise, good man, though a terrible freak. I remember once, when he was unable to provide a lecture hall, he gathered us on one of the streets of Lviv, climbed onto a street lamp and gave a long speech. Good old Lutos... ${ }^{33}$.

In 1912, the Eleusians moved away from their Father-Initiator, mainly due to the numerous excesses and extravagances of "master Wincenty" 34 , or as stated by Stanisław Pigon, due to the autocratic attitude and inconsistency of the founder. Many of the members were also dissatisfied with Lutosławski's frequent absences and trips. After the deliberations in Kosów (1910) and Żółków (1912), the Filaret Union of Eleusians was estab-

${ }^{30}$ NAWROCZYŃSKI, B., op.cit., p. 154.

31 TATARKIEWICZ, W., Historia filozofii, Warsaw 1983, vol. 3, p.359.

${ }^{32}$ Members of Eleusis were repressed by the Prussian authorities in the form of the so-called abstainers' trials in 1904 and 1905. See: NAWROCZYŃSKI, B., op. cit., p. 154.

${ }^{33}$ BYTNAR G., "Piękna młodość. Rozmowa z Olgą Drahonowską-Małkowską", Tygodnik Powszechny, 1978, no. 11.

${ }^{34}$ The authorities of the Jagiellonian University had done the same before, depriving Lutosławski of the right to lecture at the above-mentioned university. After this decision, he started to create, together with a group of devotees, the Eleusis society. The publication in 1933 of the surprising autobiography Jeden latwy żywo was also considered an extravagance on his part. Lutosławski was also accused of betraying the Eleusian ideals because he abandoned his first wife, the poet Zofia Casanova (he married her in March 1887), because of a lack of love, as he himself claimed. He then married a member of Eleusis, Wanda Peszyńska. 
lished in place of Eleusis. ${ }^{35}$ At the gathering in Kosów, Lutosławski was present, but only unofficially. He did not take part in the meetings, he only invited the members who were willing to participate in the discussions. He also appeared in Żółków, where he attacked the most active Eleusian activists, accusing them of treason, appropriation of leadership, and change of goals. It was difficult for him to accept the fact that Eleusis became independent. In its place, he created the "Order of Blacksmiths", where the chief slogans were: bravery, fitness and discipline ${ }^{36}$.

Although Lutosławski's relations with other members were getting worse, the subject of lectures at both gatherings made it clear that "Master Wincenty" was still a "spiritual father" for many sisters and brothers. In Kosów, T. Strumiłło spoke on behalf of the entire "Eleusis" about the attitude to his initiator and his current role in the society. He stated that his system [i.e. Lutosławski's - E.G-S.] of philosophy called eleuterism, is considered so contrary to the Catholic teaching that in the face of accusations of being under Lutostawski's influence - we have experienced severe assaults from the clergy, as if under the guise of religiosity, we wanted to convey views contrary to the Church's teaching - almost heretical. We need to repel this suspicion very intensively [...]. In the first place, these allegations could have been made out of ignorance, misunderstanding the development of his views, or worse, suspicion of bad will. Lutosławski himself rejected ultimate individualism that denies God, the Creator, the Almighty Father of all selves, even before Eleusis was created. On the other hand, eleuterism, reconciled with the idea of a Christian God, corresponding to the progress of philosophical European thought and characteristic of national bards, although not yet systematically presented by anyone, has nothing against Catholic teaching. It must be said, however, that Lutosławski has not yet carried out this reconciliation [...]. The fact that this issue raises a charge against Eleusis indicates a fundamental misunderstanding of our attitude to Wincenty Lutosławski. [...] We are not, as an organization, in any way dependent on him, he is neither our manager, nor leader, nor even a member of Eleusis. [...] He showed us the sources from which he drew himself. Our similarities lie in the philosophical progress of humanity, the national character of the Polish spirit, emphasized by the bards ${ }^{37}$.

Lutosławski's students included many outstanding people for Polish science and culture: the aforementioned S. Pigon' ${ }^{38}$, T. Strumiłło ${ }^{39}$, Andrzej and Olga Małkowscy,

${ }^{35}$ Materials for the history of scouts - Eleusis ...; See. STRUMIŁŁO, T., "Nasze dzieje", Harcmistrz, 1926, no. 1-2, p. 11 .

36 This organization turned out to be ephemeral, most of the blacksmiths after a short time returned to the Filaret Union. See: JACHOWSKI, J., op.cit., p. 214.

${ }^{37}$ Ibidem.

${ }^{38}$ He wrote about the Eleusian experiences in his youth in his autobiography $Z$ Komborni $w$ świat, published in Kraków in 1957.

39 JACHOWSKI, J., op.cit., p. 205. 
Józef Kostrzewski ${ }^{40}$, Adam Wodziczko, Ignacy Kozielewski, Stanisław Cywiński, Maria Jarecka, S. Prus-Szczepanowski's sister. Many Eleusis members later joined the ranks of the Polish scouts and it is thanks to the Eleusian spirit that Polish scouting has the rule of alcohol and tobacco abstinence in its Scouting $\mathrm{Law}^{41}$. Whereas, the meaning and influence of scouts on Polish youth is undisputed today.

\section{Bibliography}

ARASZKIEWICZ, f., w., Ideały wychowawcze Drugiej Rzeczypospolitej, Warsaw 1978, p. 32-37. BAGIŃSKI, H., „Geneza polskiego skautingu”, Harcerstwo, 1934, no.2, p. 55-65.

BAGIŃSKI, H., Geneza polskiego skautingu, Warsaw 1937.

BAGIŃSKI, H., U podstaw organizacji wojska polskiego 1908 - 1914, Warsaw 1935.

BŁAŻEJEWSKI, W., 50 lat harcerstwa w Polsce, Dział Rękopisów Zakładu Narodowego im. Ossolińskich, manuscript, ref. no. 14998.

BŁAŻEJEWSKI, W., Z dziejów harcerstwa polskiego 1910-1939, Warsaw 1985, p. 20-26.

BYTNAR, G., „Piękna młodość. Rozmowa z Olgą Drahonowską-Małkowską, Tygodnik Powszechny, 1978, no. 11.

Encyklopedia Historii Drugiej Rzeczypospolitej, Warsaw 1999.

GŁOWACKA, E., Życie i działalność pedagogiczna Olgi i Andrzeja Małkowskich - twórców polskiego skautingu, Poznań 2001, typescript, University Library in Poznań.

GRABSKI, S., Harcerstwo wśród organizacji młodzieży [in :] Harcerstwo polskie, ed. S. SEDLACZEK and L. GRABOWSKI, Warsaw 1925.

HAUSNER, W., Krakowski skauting 1910-1914, Kraków 1994.

JACHOWSKI, J., Harcmistrz Rzeczypospolitej (Tadeusz Strumitło 1884-1958), [in:] Byli wśród nas, ed. F. LENORT, Poznań 1978, p. 205-218.

KAMIŃSKI, A., Polskie związi młodzieży (1804-1931), Warsaw 1963.

KARWOWSKI , H.J., Prałat dr Kazimierz Lutosławski, twórca krzyża harcerskiego, Łomża 1997.

KOSTRZEWSKI, J., Z mego życia, Wrocław 1970.

KUBERSKI, L., Stanisław Szczepanowski 1846 - 1900. Przemystowiec. Polityk. Publicysta, Opole 1997.

Leksykon harcerstwa, ed. O. Fietkiewicz, Warsaw 1988, p. 433 - 434.

LEONHARD, B., Harcerski stowniczek abstynencki, Kraków 1992.

LEONHARD, B., „U źródeł profilaktyki przeciwalkoholowej w harcerstwie”, Problemy Alkoholizmu, 1970, no. 10, p. 22-24.

LUTOSŁAWSKI, W. „Filozofja narodowa”, Przegląd Filozoficzny, 1934, 37.

MAJEWSKI, F.K., Czy Eleusis pana Lutostawskiego jest katolickim czy masońskim zakonem?, Częstochowa 1910.

MARCINIAK, A., Józef Władysław Kostrzewski, [in:] Poczet wielkopolskich członków Polskiej Akademii Nauk, Poznań 2000.

Materials for the history of scouts - Eleusis, ZHP Archive, Archive of New Records, ref. no. $76 / 539$.

40 J. Kostrzewski also wrote his memoirs Z mego życia. Pamiętnik, Wrocław 1970. Also see: MARCINIAK, A., Józef Władysław Kostrzewski, [in:] Poczet wielkopolskich członków Polskiej Akademii Nauk, Poznań 2000 .

${ }^{41}$ GŁOWACKA, E., Życie i działalność pedagogiczna Olgi i Andrzeja Małkowskich-twórców polskiego skautingu, Poznań 2001, typescript, University Library in Poznań. 
MIRKIEWICZ., M., Towarzystwo Gimnastyczne „Sokót”. Mit a rzeczywistość [in:] Galicja i jej dziedzictwo, ed. A. MEISSNER and J. WYROZUMSKI, vol. 3, Rzeszów 1995, p. 269-281.

NAWROCZYŃSKI, B., Polska myśl pedagogiczna, Warsaw - Lwów 1938, p. 132.

PODGÓRSKA, T., Stowarzyszenie Patriotyczno - Religijne Eleusis w latach 1902 - 1914, Lublin 1999.

Statutes of the „Eleuteria" Society and the "Sobriety » Society, the Galician Governors in Lviv, the Central State Historical Archives of Ukraine. Branch in Lviv, ref. no. 146/58/3061-62, 306566.

STRUMIŁŁO, T., „Nasze dzieje”, Harcmistrz, 1925, no. 2, p. 13.

TATARKIEWICZ, W., Historia filozofii, Warsaw 1983, vol.3.

TOPOROWICZ, K., „Geneza i rozwój organizacyjny Towarzystwa Gimnastycznego Sokół w Krakowie w latach 1885-1914", Rocznik Naukowy Wyższej Szkoły Wychowania Fizycznego w Krakowie, vol. 5, 1966, p. 63-113.

ZAGÓRSKI, Z.M „Eleuteria - Wyzwolenie (1902-1914)”, Problemy Alkoholizmu, 1973, no. 3, p. 24-25.

„Zet” w walce o niepodległość i budowę państwa. Szkice i wspomnienia, ed. T.W. NOWACKI, Warsaw 1996.

Originally published in "Biuletyn Historii Wychowania", 2005/2006, vol. 21/22, pp. 51-57 
